\title{
First Stage of Labor
}

National Cancer Institute

\section{Source}

National Cancer Institute. First Stage of Labor. NCI Thesaurus. Code C92798.

The stage of the labor and childbirth process when the uterine contractions become strong and regular with cervical effacement and complete dilation of the cervix. 